\title{
Biochemical, antimicrobial susceptibility and genotyping studies on Corynebacterium urealyticum isolates from diverse sources
}

\author{
E. NIETO, A. VINDEL*, P. L. VALERO-GUILLÉN†, J. A. SAEZ-NIETO* and F. SORIANO \\ Department of Medical Microbiology, Fundación Jiménez Díaz, Madrid, * Servicio de Bacteriología, Centro \\ Nacional de Microbiología, Instituto de Salud Carlos III, Majadahonda, Madrid and †Department of Genetic and \\ Microbiology, University of Murcia, Spain
}

\begin{abstract}
Thirty-two isolates of Corynebacterium urealyticum, isolated between 1991 and 1995, were studied by biochemical tests, phospholipid content, analysis of fatty and mycolic acids, ribotyping, whole-cell protein patterns and antimicrobial susceptibility to six antibiotics. Nineteen isolates were from human and human-related sources (HHRS); the remainder were from animal and animal-related sources (AARS). Most $C$. urealyticum isolates were similar in their biochemical and whole-cell protein profiles, although most HHRS isolates were alkaline phosphatase-positive $(84 \%)$ and produced almost identical protein patterns, whereas AARS isolates were quite diverse. The qualitative composition of cellular fatty acids was identical for all isolates examined. Twelve different ribotypes were obtained with HindIII producing four-to-seven bands. Ribotypes 8, 9 and 10 were predominant in isolates from HHRS, whereas in isolates from AARS, ribotypes 5 and 6 predominated. AARS isolates were significantly less antibiotic-resistant, in comparison with HHRS isolates. Ribotyping appeared to be the most useful tool for strain characterisation.
\end{abstract}

\section{Introduction}

Corynebacterium urealyticum is one of the more common Corynebacterium species isolated from human clinical specimens, mainly those from the urinary tract [1]. It has also been found on healthy human skin in hospitalised patients [2] behaving as an opportunistic pathogen. C. urealyticum has been isolated from the hospital environment [3], which suggests that it could be transmitted nosocomially and an outbreak of nosocomial infection has been described [4]. $C$. urealyticum has also been isolated from some animal infections [5,6] and healthy animal skin [7].

C. urealyticum isolates were previously found to be susceptible to many antibiotics, but more recent isolates have developed antimicrobial resistance [8]. The species appears to be homogeneous with respect to biochemical tests and antibiograms, making it difficult to differentiate among isolates derived from diverse sources.

Received 7 July 1999; revised version received 30 Dec. 1999; accepted 4 Jan. 2000.

Corresponding author: Dr F. Soriano (e-mail: fsoriano@, microb.net).
The aims of this study were to examine the diversity within C. urealyticum isolates from various sources and to evaluate the usefulness of a range of typing methods.

\section{Materials and methods}

\section{C. urealyticum isolates}

Table 1 describes the 19 isolates from human and human-related sources (HHRS) and the 13 isolates from animals and animal-related sources (AARS) that were studied. All were isolated in the period 19911995. The isolates from human skin (staff and patients) and from the environment were obtained during a 3week period in the orthopaedic surgery department and the microbiology laboratory at this hospital (FJD). All except one of the human clinical isolates were also isolated at FJD, some being consecutive isolates from the same patients. Skin isolates were obtained from animals housed by the Society for the Prevention of Cruelty to Animals and Plants (SPCAP) and in FJD, in addition to isolates from the animals' environment. Two isolates from canine infections were included; their case reports were published earlier $[5,6]$. Air samples were taken with a Surface Air System (PBI, Lab-center, Italy). Skin and surface samples were 
Table 1. Main characteristics of C. urealyticum isolates from HHRS and AARS

\begin{tabular}{|c|c|c|c|c|c|c|c|c|c|c|}
\hline \multirow[b]{2}{*}{ Source (isolate no.) } & \multirow[b]{2}{*}{ Room* } & \multirow[b]{2}{*}{ Ribotype } & \multirow[b]{2}{*}{$\mathrm{P} 45^{\dagger}$} & \multirow[b]{2}{*}{ PAL } & \multicolumn{6}{|c|}{ Antimicrobial susceptibility } \\
\hline & & & & & $\mathrm{AM}$ & GN & NOR & ER & TE & $\mathrm{RF}$ \\
\hline FJD, urine, patient $1^{*}$ (11) & $\mathrm{X}$ & 9 & + & + & $\mathrm{R}$ & $\mathrm{R}$ & $\mathrm{R}$ & $\mathrm{R}$ & $\mathrm{R}$ & $\mathrm{R}$ \\
\hline FJD, urine, patient $1^{*}(12)$ & $\mathrm{X}$ & 9 & + & + & $\mathrm{R}$ & $\mathrm{R}$ & $\mathrm{R}$ & $\mathrm{R}$ & $\mathrm{R}$ & $\mathrm{R}$ \\
\hline FJD, urine, patient 2 & $\mathrm{Y}$ & 9 & + & + & $\mathrm{S}$ & $\mathrm{R}$ & $\mathrm{S}$ & $\mathrm{R}$ & $\mathrm{S}$ & $\mathrm{S}$ \\
\hline FJD, urine, patient 2 (32) & $\mathrm{Y}$ & 9 & + & - & $\mathrm{R}$ & $\mathrm{R}$ & $\mathrm{R}$ & $\mathrm{R}$ & $\mathrm{S}$ & $\mathrm{S}$ \\
\hline HDO, urine, patient 3 (13) & $\mathrm{Z}$ & 9 & + & + & $\mathrm{R}$ & $\mathrm{R}$ & $\mathrm{R}$ & $\mathrm{S}$ & $\mathrm{R}$ & $\mathrm{S}$ \\
\hline FJD, skin, patient 4 (25) & A & 8 & + & + & $\mathrm{R}$ & $\mathrm{R}$ & $\mathrm{R}$ & $\mathrm{R}$ & $\mathrm{R}$ & $\mathrm{R}$ \\
\hline FJD, skin, patient 5 (26) & A & 8 & + & + & $\mathrm{R}$ & $\mathrm{R}$ & $\mathrm{R}$ & $\mathrm{R}$ & $\mathrm{R}$ & $\mathrm{R}$ \\
\hline FJD, skin, patient $6^{+}(28)$ & $\mathrm{B}$ & 10 & + & + & $\mathrm{R}$ & $\mathrm{R}$ & $\mathrm{R}$ & $\mathrm{R}$ & $\mathrm{R}$ & $\mathrm{R}$ \\
\hline FJD, skin, patient $6^{*}(29)$ & $\mathrm{B}$ & 10 & + & + & $\mathrm{R}$ & $\mathrm{R}$ & $\mathrm{R}$ & $\mathrm{R}$ & $\mathrm{R}$ & $\mathrm{R}$ \\
\hline FJD, air in ward (14) & A & 8 & + & + & $\mathrm{R}$ & $\mathrm{R}$ & $\mathrm{R}$ & $\mathrm{R}$ & $\mathrm{R}$ & $\mathrm{R}$ \\
\hline FJD, air in ward (15) & A & 8 & + & + & $\mathrm{R}$ & $\mathrm{R}$ & $\mathrm{R}$ & $\mathrm{R}$ & $\mathrm{R}$ & $\mathrm{R}$ \\
\hline SFJD, air in ward (24) & A & 7 & - & + & $\mathrm{R}$ & $\mathrm{S}$ & $\mathrm{S}$ & $\mathrm{R}$ & $\mathrm{S}$ & $\mathrm{S}$ \\
\hline FJD, air in ward (16) & $\mathrm{B}$ & 8 & + & + & $\mathrm{R}$ & $\mathrm{R}$ & $\mathrm{R}$ & $\mathrm{R}$ & $\mathrm{R}$ & $\mathrm{R}$ \\
\hline FJD, air in ward (19) & $\mathrm{C}$ & 2 & + & - & $\mathrm{S}$ & $\mathrm{R}$ & $\mathrm{R}$ & $\mathrm{R}$ & $\mathrm{R}$ & $\mathrm{R}$ \\
\hline FJD, air in ward (17) & $\mathrm{D}$ & 9 & + & - & $\mathrm{R}$ & $\mathrm{R}$ & $\mathrm{R}$ & $\mathrm{R}$ & $\mathrm{R}$ & $\mathrm{R}$ \\
\hline FJD, air in ward (18) & $\mathrm{D}$ & 9 & - & + & $\mathrm{R}$ & $\mathrm{S}$ & $\mathrm{R}$ & $\mathrm{R}$ & $\mathrm{S}$ & $\mathrm{S}$ \\
\hline FJD, nurse I, hand (27) & $A-D$ & 10 & + & + & $\mathrm{R}$ & $\mathrm{R}$ & $\mathrm{R}$ & $\mathrm{R}$ & $\mathrm{S}$ & $\mathrm{S}$ \\
\hline FJD, nurse II, hand (30) & $\mathrm{A}-\mathrm{D}$ & 9 & + & + & $\mathrm{R}$ & $\mathrm{R}$ & $\mathrm{R}$ & $\mathrm{R}$ & $\mathrm{S}$ & $\mathrm{S}$ \\
\hline FJD, air in laboratory (23) & Laboratory & 11 & + & + & $\mathrm{R}$ & $\mathrm{R}$ & $\mathrm{R}$ & $\mathrm{R}$ & $\mathrm{S}$ & $\mathrm{I}$ \\
\hline $\mathrm{PO} /$ Israel, $\operatorname{dog} 1$, urine (1) & $\ldots$ & 1 & + & - & $\mathrm{R}$ & $\mathrm{R}$ & $\mathrm{R}$ & $\mathrm{R}$ & $\mathrm{R}$ & $\mathrm{R}$ \\
\hline PO/Spain, dog 2, urine (2) & $\ldots$ & 4 & + & + & $\mathrm{R}$ & $\mathrm{R}$ & $\mathrm{R}$ & $\mathrm{R}$ & $\mathrm{R}$ & $\mathrm{R}$ \\
\hline SPCAP, dog 3, skin (3) & $\ldots$ & 5 & + & + & $\mathrm{S}$ & $\mathrm{S}$ & $\mathrm{S}$ & $\mathrm{R}$ & $\mathrm{R}$ & $\mathrm{S}$ \\
\hline SPCAP, dog 3, skin (4) & $\ldots$ & 5 & - & - & $\mathrm{S}$ & $\mathrm{S}$ & $\mathrm{S}$ & $\mathrm{S}$ & $\mathrm{S}$ & $\mathrm{S}$ \\
\hline SPCAP, dog 4, skin (5) & $\ldots$ & 5 & - & + & $\mathrm{S}$ & $\mathrm{S}$ & $\mathrm{S}$ & $\mathrm{S}$ & $\mathrm{S}$ & $\mathrm{S}$ \\
\hline SPCAP, $\operatorname{dog} 5$, skin (22) & $\ldots$ & 12 & - & + & $\mathrm{S}$ & $\mathrm{S}$ & $\mathrm{S}$ & $\mathrm{S}$ & $\mathrm{S}$ & $\mathrm{S}$ \\
\hline FJD, rat 1 , skin (6) & $\ldots$ & 9 & + & - & $\mathrm{R}$ & $\mathrm{R}$ & $\mathrm{R}$ & $\mathrm{S}$ & $\mathrm{R}$ & $\mathrm{S}$ \\
\hline FJD, rat 2, skin (20) & $\ldots$ & 3 & - & - & $\mathrm{S}$ & $\mathrm{S}$ & $\mathrm{S}$ & $\mathrm{I}$ & $\mathrm{S}$ & $\mathrm{S}$ \\
\hline FJD, mouse, skin (21) & $\ldots$ & 8 & + & + & $\mathrm{R}$ & $\mathrm{R}$ & $\mathrm{R}$ & $\mathrm{R}$ & $\mathrm{R}$ & $\mathrm{R}$ \\
\hline FJD, rat cage I (7) & $\ldots$ & 6 & - & - & $\mathrm{S}$ & $\mathrm{S}$ & $\mathrm{S}$ & $\mathrm{S}$ & $\mathrm{S}$ & $\mathrm{S}$ \\
\hline FJD, rat cage II (8) & $\ldots$ & 6 & - & - & $\mathrm{S}$ & $\mathrm{S}$ & $\mathrm{S}$ & $\mathrm{S}$ & $\mathrm{S}$ & $\mathrm{S}$ \\
\hline FJD, air in animal ward (9) & $\ldots$ & 6 & - & - & $\mathrm{S}$ & $\mathrm{S}$ & $\mathrm{S}$ & $\mathrm{S}$ & $\mathrm{S}$ & $\mathrm{S}$ \\
\hline FJD, animal-keeper, hand (10) & $\ldots$ & 6 & - & - & $\mathrm{R}$ & $\mathrm{S}$ & $\mathrm{S}$ & $\mathrm{S}$ & $\mathrm{S}$ & $\mathrm{S}$ \\
\hline
\end{tabular}

AM, ampicillin; GN, gentamicin; NOR, norfloxacin; ER, erythromycin; TE, tetracycline; RF, rifampin; S, sensitive; I, intermediate; R, resistant; FJD, Fundación Jiménez Díaz; HDO, Hospital Doce de Octubre; PO, private owner; SPCAP, Society for the Prevention of Cruelty to Animals and Plants.

* Rooms A-D belong to the orthopaedic surgery department at FJD. Room A had only colonised patients; room B had at least one colonised patient; rooms $\mathrm{C}$ and $\mathrm{D}$ had one non-colonised patient and the other patient was not fully investigated.

Protein close to $45 \mathrm{kDa}$.

tTwo consecutive isolates showing the same patterns.

obtained by the swab-rinse method and by direct contact on to a petri dish.

\section{Biochemical tests and chemotaxonomic studies}

All isolates were identified by commercial test kits and conventional biochemical tests [9]. The API Coryne System with databases 1.0 and 2.0 (bioMérieux, Marcy-l'Etoile, France) was used according to the manufacturer's instructions. Alkaline phosphatase (PAL) was tested as described by MacFaddin [10], but without heating.

The phospholipid, mycolic and fatty acid studies were performed as described previously [11].

\section{Whole-cell protein patterns}

These were determined by SDS-PAGE as described previously [12], with a pre-stained standard (BioRad Laboratories, USA) as the molecular mass marker. The percentage similarity of test isolates and reference strains (C. urealyticum NCTC $12011^{\mathrm{T}}$, ATCC $43042^{\mathrm{T}}$ ) was estimated by using the Dice coefficient, with NIH Image 1.6 [13].

\section{Ribotyping}

After DNA extraction [14], restriction fragments obtained with $15 \mathrm{U}$ of HindIII were separated by conventional electrophoresis on an agarose $0.8 \% \mathrm{w} / \mathrm{v}$ gel and transferred to membranes [15]. Pre-hybridisation was performed with $5 \times \mathrm{SCC}$-lauryl sarcosine $0.1 \% \mathrm{w} / \mathrm{v}$, SDS $0.02 \% \mathrm{w} / \mathrm{v}$, blocking agent (1096176; Boehringer Mannheim GmbH, Mannheim, Germany) 1\%. Escherichia coli $16 \mathrm{~S}+23 \mathrm{~S}$ rDNA (Boehringer Mannheim) labelled with digoxigenin was used as the probe. The hybridisation was performed overnight at 
$60^{\circ} \mathrm{C}$ and the hybridisation bands were visualised with 4-nitroblue tetrazolium bromide and 5-bromo-4-chloro3-indolylphosphate (Boehringer Mannheim). DNA mol. wt marker II Dig-labelled (Boehringer Mannheim) was used. A ribotyping pattern was interpreted on the basis of a single band difference. Percentage similarities were determined by Dice coefficient and UPGMA clustering for the data analysis.

\section{Antimicrobial susceptibility testing}

Susceptibility was determined by the disk diffusion method as described previously [16] with disks containing ampicillin $10 \mu \mathrm{g}$, gentamicin $10 \mu \mathrm{g}$, norfloxacin $10 \mu \mathrm{g}$, erythromycin $15 \mu \mathrm{g}$, tetracycline $30 \mu \mathrm{g}$ and rifampin $5 \mu \mathrm{g}$ (Difco).

\section{Results}

\section{Biochemical tests and chemotaxonomic studies}

Conventional test results were indistinguishable for all isolates studied. PAL was positive in $84 \%$ of HHRS isolates and in $31 \%$ of AARS isolates (Table 1) (Fisher's exact test, $\mathrm{p}<0.01$ ). The API-Coryne kit identified all $C$. urealyticum strains correctly with both versions of the database (1.0 and 2.0). Lipid composition and the content of mycolic acids of 24-32 carbon atoms correlated with previous reports [11]. Fatty acids ranged from 14 to 20 carbon atoms, C16:0 (26\%), C18:0 (15\%), C18:1 (19\%) and C18:2 (20\%) being the major components. Tuberculostearic acid (5\%) and 10methylene-octadecanoic acid (2\%) were also found. Qualitative profiles were similar amongst isolates, and although some quantitative differences were observed, there was no correlation with source.

\section{Whole-cell protein patterns}

Most of the isolates studied had a Dice coefficient $>90 \%$. A band close to $45 \mathrm{kDa}$ was present in the $C$. urealyticum reference strain but not in $31 \%$ of AARS nor $10 \%$ of HHRS isolates (Table 1).

\section{Ribotyping}

Twelve different ribotypes with four-to-seven bands were obtained. Ribotypes 8 and 9 comprised $47 \%$ of isolates (Fig. 1). Seven clusters and eight subclusters could be distinguished at a similarity level of 39-91\%. Some ribotypes $(2,7,10$ and 11) were found only in HHRS isolates, whilst others (1, 3, 4, 5, 6 and 12) were found only in AARS isolates.

The C. urealyticum isolates from 'non-related' patients (with respect to time and date) were of ribotype 9 and had several different antimicrobial susceptibility patterns. Patients from Room A were colonised by multiresistant, ribotype 8 isolates. The same pattern was found in air samples from rooms A and B. Two multiresistant isolates of ribotype 10 were obtained from a patient in room B. C. urealyticum was not isolated from patients in rooms $\mathrm{C}$ and $\mathrm{D}$, although isolates of ribotypes 2 and 9 were obtained from the air in these rooms. Isolates of ribotypes 9 and 10 were isolated from two nurses attending rooms $\mathrm{A}-\mathrm{D}$.

The multiresistant isolates from unrelated dogs with infections showed different ribotypes (1 and 4). Three different isolates colonising SPCAP dogs belonged to ribotype 5. The isolates from FJD animals showed different ribotypes and antibiograms. Isolates from two animal cages, the air in the animals' room and an animal-keeper's hand were of ribotype 6 .

\section{Antimicrobial susceptibility testing}

The susceptibility test results (Table 1) showed that HHRS isolates were significantly more antibioticresistant than AARS isolates for all drugs tested except tetracycline (Fisher's exact test, $\mathrm{p}<0.05$ ).

\section{Discussion}

Differences for PAL reaction, antibiotic susceptibility and whole-cell protein patterns have been observed between HHRS and AARS isolates of C. urealyticum; some of these differences were statistically significant. The higher rate of antibiotic resistance in HHRS isolates may be due to selective pressure of antibiotics in the human environment. The present study showed that rRNA gene probing is a sensitive measure of variation between clinical and environmental strains in C. urealyticum. Two previously reported isolates from patient 2 [17], with different antimicrobial susceptibility and PAL reaction, exhibited an identical ribotype which showed that this profile appeared to be more stable than the antibiogram and biotype and could be of greater value for epidemiological purposes. Ribotypes 9 and 10 were prevalent among isolates from the air and skin and were the ribotypes found on the hands of nurses attending the whole ward, which suggests that cross-contamination may occur in hospital wards, either through the air or on hands.

Isolates from canine infections had different ribotypes and also differed from those seen in human infections. The finding of the same ribotype in related AARS isolates suggests that cross-contamination may have occurred.

It may be concluded that there was diversity amongst C. urealyticum isolates from various sources and that ribotyping appeared to be the most useful tool for strain characterisation. Although epidemiologically related isolates showed the same ribotype, as no incidents of cross-infection were detected in this study it was not possible to draw conclusions about the usefulness of ribotyping to demonstrate epidemiological relationships among $C$. urealyticum isolates 


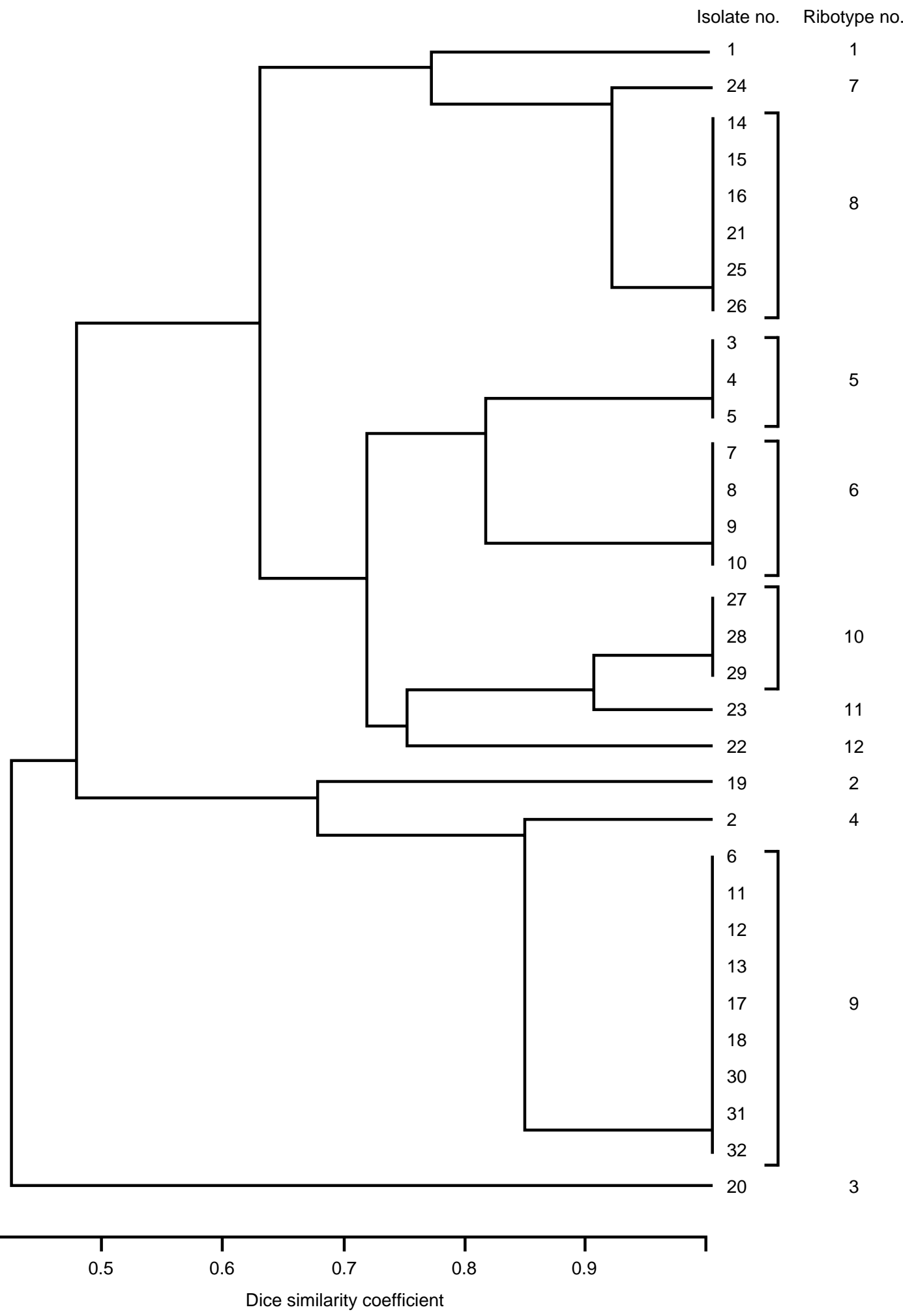

Fig. 1. Dendrogram showing similarity values of rRNA profiles of $C$. urealyticum isolates.

from colonised and infected individuals. However, it is now well established that this species is a common coloniser of skin in both man and animals, and because it may be isolated from air, environmental surfaces and hands, it is possible that cross-contamination may occur.

E. N. was aided by a scholarship from the Fundación Conchita Rábago, Madrid, Spain.

\section{References}

1. Soriano F, Aguado JM, Ponte C, Fernández-Roblas R, Rodriguez-Tudela JL. Urinary tract infection caused by Corynebacterium group D2: report of 82 cases and review. Rev Infect Dis 1990; 12: 1019-1034.

2. Soriano F, Rodriguez-Tudela JL, Fernández-Roblas R, Aguado JM, Santamaría M. Skin colonization by Corynebacterium groups D2 and JK in hospitalized patients. J Clin Microbiol 1988; 26: $1878-1880$

3. Nieto E, Zapardiel J, Soriano F. Environmental contamination 
by Corynebacterium urealyticum in a teaching hospital. $J$ Hosp Infect 1996; 32: 78-79.

4. Fosse T, Carles D, Laffont J, Lefebvre JC, Bocquet JP. Infections urinaires à Corynebacterium au groupe D2. Epidémie hospitalière et sensibilité aux antibiotiques. [Urinary Corynebacterium group D2 infections. A hospital epidemic and antibiotic sensitivity.] Pathol Biol 1988; 36: 742-745.

5. Elad D, Aizenberg I, Shamir M, Soriano F, Shlomovitz S. Isolation of Corynebacterium group D2 from two dogs with urinary tract infections. $J$ Clin Microbiol 1992; 30: 1167-1169.

6. Gómez A, Nombela C, Zapardiel J, Soriano F. An encrusted cystitis caused by Corynebacterium urealyticum in a dog. Aust Vet $J$ 1995; 72: 72-73.

7. Nieto E, Rupérez C, Elad D, Ponte C, Soriano F. Colonización animal y ambiental por Corynebacterium urealyticum. VIII Congreso SEIMC, Palma de Mallorca, 1998. Abstract no. 22-3.

8. Santamaría M, Ponte C, Wilhelmi L, Soriano F. Antimicrobial susceptibility of Corynebacterium group D2. Antimicrob Agents Chemother 1985; 28: 845-846.

9. Funke G, von Graevenitz A, Clarridge JE, Bernard KA. Clinical microbiology of coryneform bacteria. Clin Microbiol Rev 1997; 10: 125-159.

10. MacFaddin JF. Biochemical tests for identification of medical bacteria. Baltimore, Williams \& Wilkins. 1976: 1-4.
11. Herrera-Alcaraz EA, Valero-Guillén PL, Martin-Luengo F Soriano F. Taxonomic implications of the chemical analysis of the D2 group of corynebacteria. FEMS Microbiol Lett 1990; 72: $341-344$

12. Barreau C, Bimet F, Kiredjian M, Rouillon N, Bizet C. Comparative chemotaxonomic studies of mycolic acid-free coryneform bacteria of human origin. J Clin Microbiol 1993; 31: 2085-2090.

13. Chow D, Evans J. Using Image for densitometric analysis of 1$\mathrm{D}$ gels. Bethesda, MD, Center for Information Technology, National Institutes of Health.

14. Pitcher DG, Owen RJ, Dyal P, Beck A. Synthesis of a biotinylated DNA probe to detect ribosomal RNA cistrons in Providencia stuartii. FEMS Microbiol Lett 1987; 48: 283-287.

15. Southern EM. Detection of specific sequences among DNA fragments separated by gel electrophoresis. J Mol Biol 1975; 98: $503-517$.

16. Martínez-Martínez L, Ortega MC, Suárez AI. Comparison of E-test with broth microdilution and disk diffusion for susceptibility testing of coryneform bacteria. J Clin Microbiol 1995; 33: 1318-1321.

17. Zapardiel J, Nieto E, Soriano F. Urinary tract infections caused by beta-lactam-sensitive Corynebacterium urealyticum strains. Eur J Clin Microbiol Infect Dis 1997; 16: 174-176. 